\title{
Kajian Perkerasan Jalan Menggunakan Metode Analisa Komponen (Studi Kasus Peningkatan Jalan Simpang Talang Babat - Pangkal Bulian Kabupaten Tanjung Jabung Timur)
}

\author{
${ }^{1}$ Fakhrul Rozi Yamali, ${ }^{2}$ M. Nuklirullah, ${ }^{3}$ A. Rahman Saparudin \\ ${ }^{1}$ Dosen Fakultas Teknik Sipil Universitas Batanghari Jambi \\ ${ }^{2}$ Mahasiswa Teknik Sipil Universitas Batanghari Jambi \\ Email : fakhrul65@gmail.com
}

\begin{abstract}
Abstrak
Kabupaten Tanjung Jabung Timur merupakan Kabupaten yang terletak di Provinsi Jambi, yang mana tingkat pertumbuhan penduduknya cukup tinggi dan perkembangan ekonominya selalu meningkat dari tahun ke tahun, hal ini dapat diketahui dari jumlah pertumbuhan kendaraan di Kabupaten Tanjung Jabung Timur. Kondisi tersebut menuntut tersedianya fasilitas yang semakin baik, terutama menyangkut prasarana transportasi. Akibat bertambahnya volume lalulintas berdampak juga pada prasarana jalan, salah satunya perkerasan jalan. Ruas jalan simpang Talang Babat - Pangkal Bulian, merupakan salah satu jalan Kolektor Sekunder dan memiliki beban Lalu Lintas Harian yang cukup tinggi, dengan mencermati hal tersebut maka perlunya mengevaluasi kembali perkerasan jalan yang pada tahun 2017 terjadi peningkatan jalan berupa penambahan lebar lapis perkerasan sebanyak 2,5 m pada jalur kiri dan kanan, dengan panjang jalan 3,4 km dan memiliki tebal lapis perkerasan AC - BC $6 \mathrm{~cm}$. Jumlah LHR yang cukup tinggi akan menyebabkan jalan mengalami kerusakan. Berdasarkan hal tersebut, penulis melakukan penelitian mengenai Kajian Perkerasan Jalan Menggunakan Metode Analisa Komponen. Perencanaan ini dimulai dengan survey jumlah kendaraan yang lewat selama 3 hari, kemudian mencari referensi dan data - data sekunder berupa pertumbuhan lalu lintas, data curah hujan dan data kelas jalan. Setelah semua data yang dibutuhkan didapat kemudian dilakukan perhitungan tebal perkerasan jalan menggunakan metode Analisa Komponen. Berdasarkan perhitungan tersebut didapat lapis tambah yang diperlukan adalah $4 \mathrm{~cm}$.
\end{abstract}

Kata Kunci :Perkerasan Jalan, Tebal Lapis, Metode Analisa Komponen.

\section{PENDAHULUAN}

Jaringan jalan memiliki fungsi yang sangat penting, yaitu sebagai prasarana untuk memindahkan transportasi orang dan barang, yang merupakan urat nadi untuk mendorong pertumbuhan ekonomi, sosial, budaya dan stabilitas nasional, serta upaya pemerataan dan penyebaran pembangunan. Dalam dimensi yang lebih luas, jaringan jalan mempunyai peranan yang besar dalam pengembangan suatu wilayah, baik wilayah secara nasional, provinsi, maupun kabupaten/ kota sesuai dengan fungsi dari jaringan jalan tersebut. (Shirley L. Hendarsin, 2000).

Jalan yang memiliki arus lalu lintas yang tinggi dan beban lalu lintas yang berat harus diimbangi oleh kondisi perkerasan jalan yang baik, salah satunya adalah jalan simpang Talang Babat - Pangkal Bulian Kabupaten Tanjung Jabung Timur.

Perencanaan tebal perkerasan jalan di Indonesia umumnya menggunakan nilai CBR (California Bearing Ratio) Setelah nilai CBR segmen diperoleh, maka untuk menentukan nilai DDT digunakan grafik korelasi antara nilai CBR dengan DDT (Grafik) dengan cara menghubungkan nilai CBR segmen dengan garis mendatar kesebelah kiri maka diperoleh nilai DDT.

Berdasarkan pengamatan langsung kondisi permukaan jalan Simpang Talang Babat Pangkal Bulian sudah mengalami kerusakan berupa retak di beberapa bagian. Oleh karena itu diperlukan peapisan ulang atau overlay. Perencanaan tebal perkerasan jalan ini menggunakan metode Analisa Komponen. 


\section{Landasan Teori}

\section{Perkerasan lentur (flexible pavement)}

Adalah perkerasan yang menggunakan aspal sebagai bahan pengikat. Lapisan lapisan perkerasannya bersifat memikul dan menyebarkan beban lalu lintas ke tanah dasar.

Konstruksi perkerasan lentur terdiri dari lapisan - lapisan yag diletakkan diatas tanah dasar yang telah dipadatkan. Lapisan - lapisan tersebut berfungsi untuk menerima beban lalulintas dan menyebarkan ke lapisan di bawahnya.Konstruksi perkerasan lentur terdiri dari empat lapisan, antara lain seperti pada berikut:
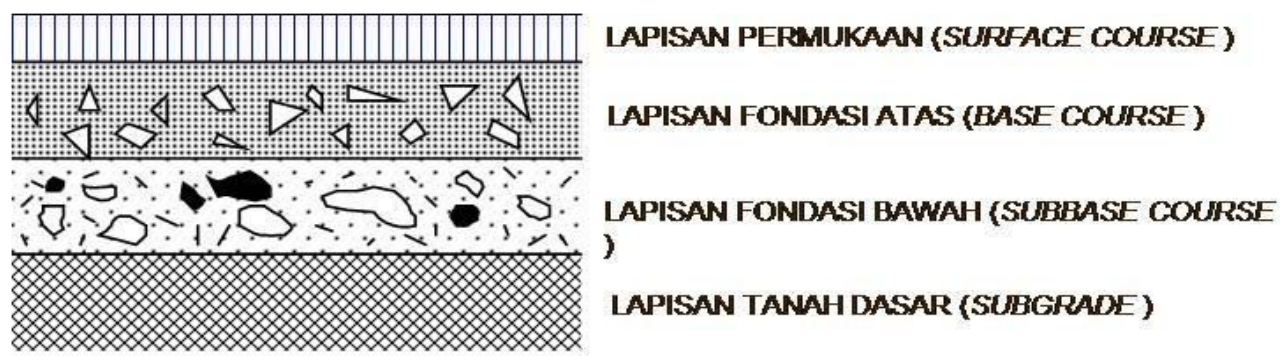

Sumber : Silvia Sukirman, 1999

Gambar. 1 Lapisan Perkerasan Lentur

\section{Metode Analisa Komponen}

Perhitungan perencanaan ini didasarkan pada kekuatan relatif masing-masing lapisan perkerasan, dimana penentuan tebal perkerasan dinyatakan oleh ITP (Indeks Tebal Perkerasan), dengan rumus sebagai berikut:

ITP $=a_{1} . D_{1}+a_{2} . D_{2}+a_{3} . D_{3}$

Keterangan:

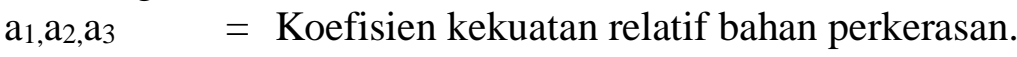

$\mathrm{D}_{1,} \mathrm{D}_{2}, \mathrm{D}_{3}=$ Tebal masing-masing lapis perkerasan $(\mathrm{cm})$.

Angka ${ }_{1,2,3}=$ Masing-masing untuk lapis permukaan lapis pondasi dan lapis pondasi.

\section{METODE}

\section{Lokasi Penelitian}

Penelitian ini dilakukan di simpang Talang Babat - Pangkal Bulian, Kecamatan Muara Sabak Barat, Kabupaten Tanjung Jabung Timur, dengan panjang penelitian 3, 4 km mulai dari sta $0+000 \mathrm{~s} / \mathrm{d}$ sta $3+400$.

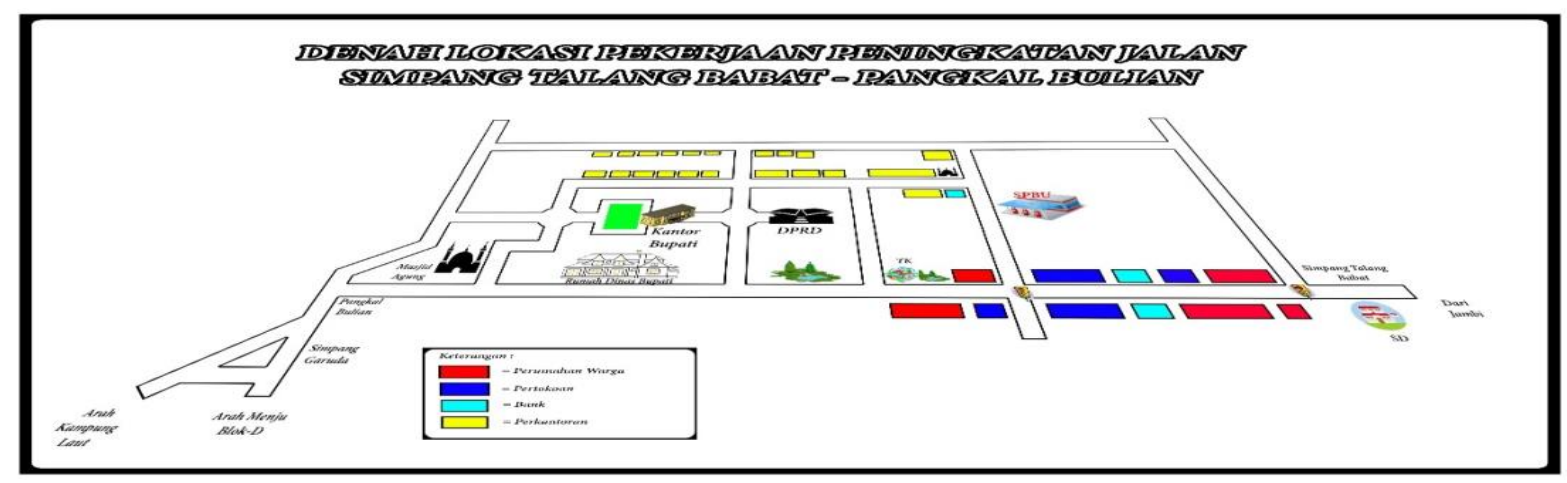

Sumber :data olahan, 2017

Gambar. 2 Denah Lokasi Penelitian 


\section{Metode Pengumpulan Data}

1. Data Primer adalah Data yang dikumpulkan langsung pada serangkaian kegiatan pengujian yang dilakukan sendiri yang mengacu berdasarkan petunjuk manual yang ada. Adapun yang termasuk data primer dalam penelitian ini yaitu data panjang lebar jalan dan data lalu lintas harian rata - rata.

2. Data Sekunder adalah Data yang diperoleh secara tidak langsung. Data ini diperoleh dari peneliti atau sumber lain. Adapun yang termasuk data sekunder dalam penelitian ini adalah Data Curah Hujan di ambil dari Badan Pusat Statistik Kabupaten Tanjung Jabung Timur dan Data California Bearing Ratio (CBR) diperoleh dari Dinas Pekerjaan Umum dan Penataan Ruang Kabupaten Tanjung Jabung Timur.

\section{Bagan Alir (Flowchart)}

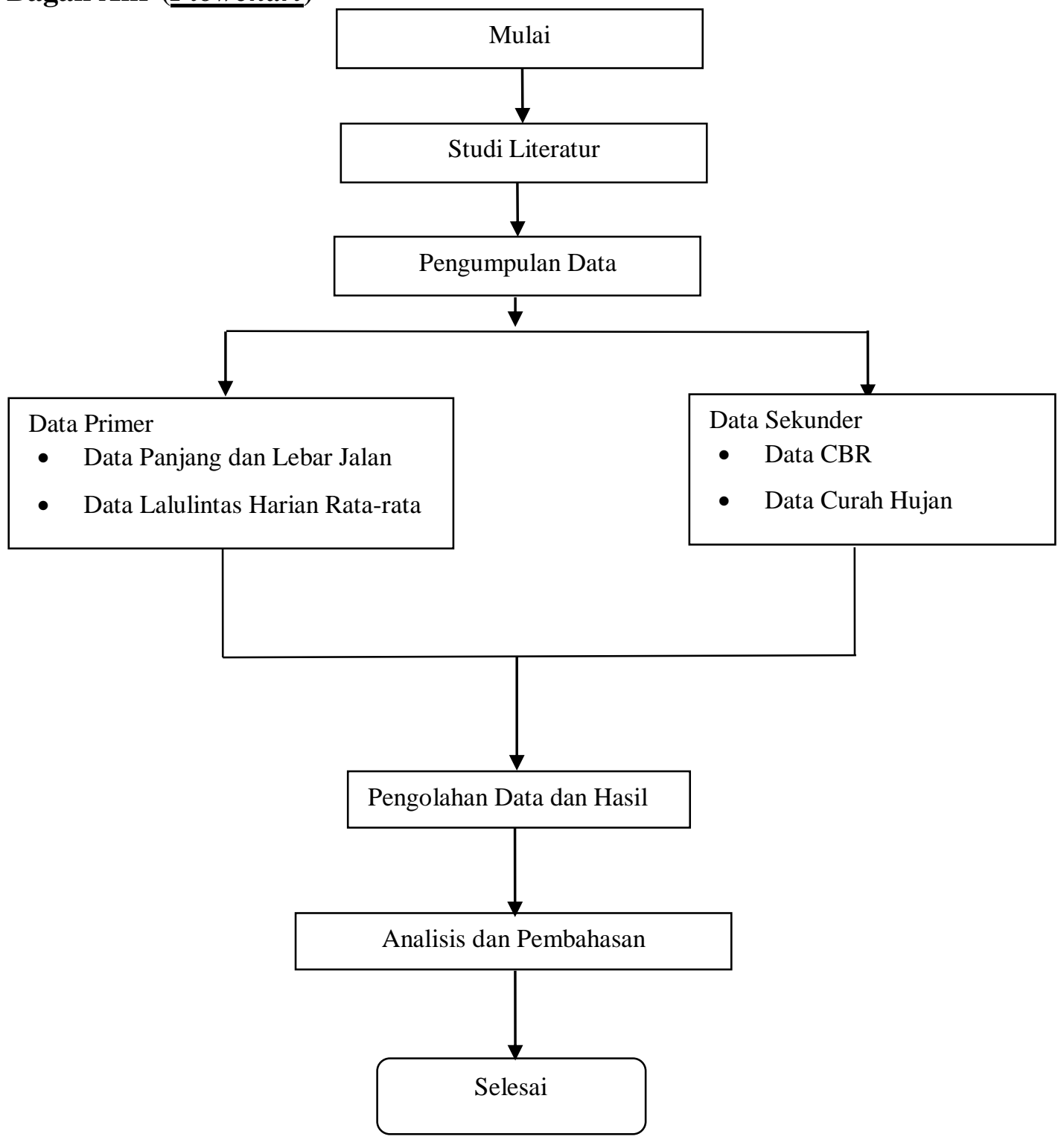

Sumber : Data Olahan (2018)

Gambar. 3 Bagan Alir Penelitian

Bagan Alir Metode Analisa Komponen

Perencanaan perkerasan jalan dengan Metode Analisa Komponen memiliki beberapa 
parameter penting yang harus dianalisis dengan urutan seperti pada Gambar dibawah ini.

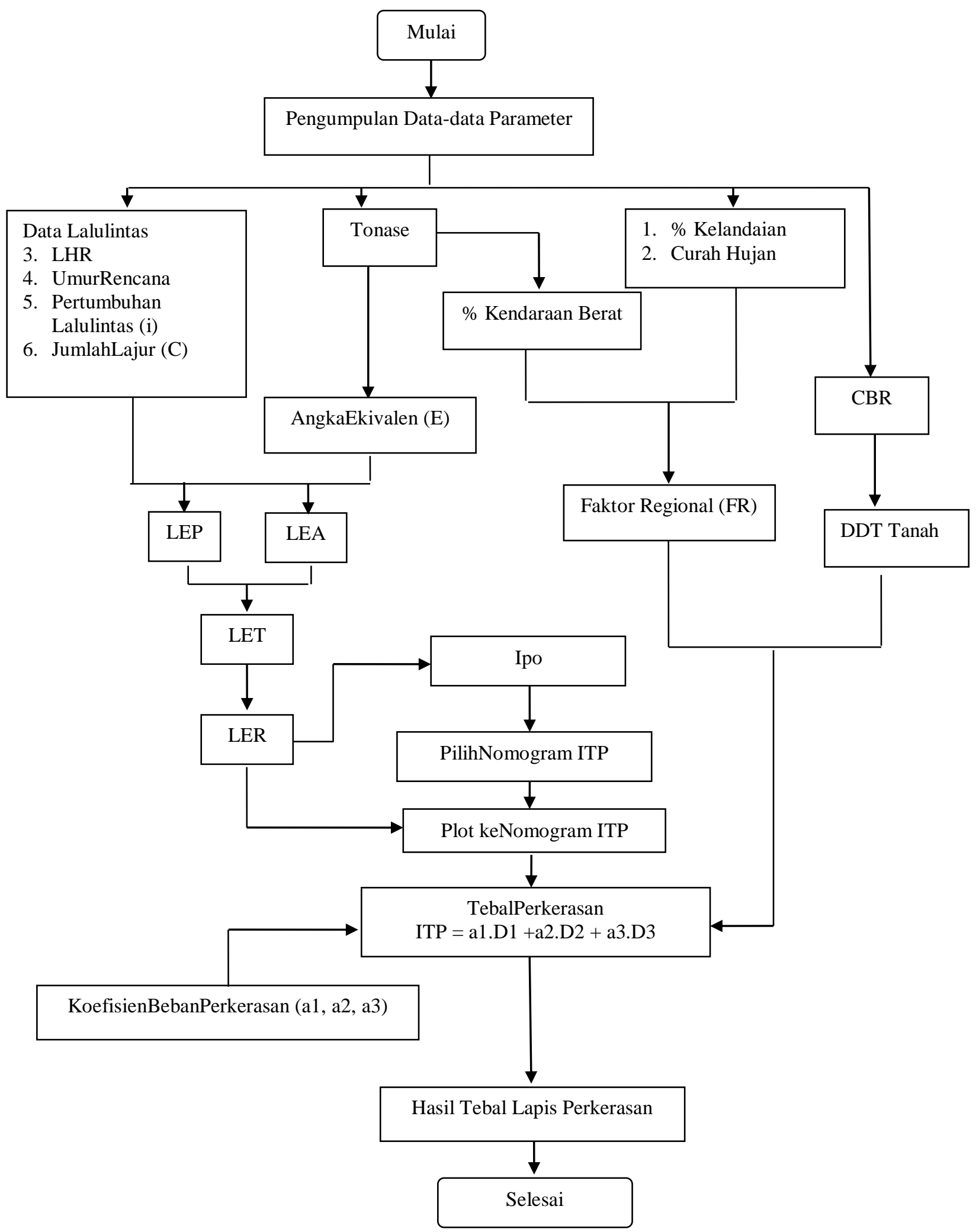

Sumber : Data Olahan (2018)

Gambar. 4 Bagan Alir Metode Analisa Komponen 


\section{HASIL}

\section{Perhitungan Tebal Perkerasan}

Berdasarkan pengukuran dan pengamatan di lapangan diperoleh data sebagai berikut :

a. Komposisi LHR awal umur rencana pada tahun 2018

Pengamatan dilakukan pada tanggal 27 s/d 29 Agustus 2018 dimulai pukul 08.00 s/d 18.00 Wib.

Tabel 1 LHR Awal Umur Rencana

\begin{tabular}{lcc}
\hline \multicolumn{1}{c}{ Jenis Kendaraan } & Jumlah Kendaraan Lajur A - B & Jumlah Kendaraan Lajur B - A \\
\hline Kendaraan Ringan (KR) & 1236 & 1189 \\
Bus Sedang (BS) & 309 & 287 \\
Truk Sedang 2 As (Ts 2A) & 169 & 153 \\
Truk Besar 2 As (TB 2A) & 34 & 27 \\
\hline
\end{tabular}

Sumber : Data Olahan (2018)

b. Perhitungan LHR akhir umur rencana $\left(\operatorname{LHR}(\mathrm{n})=\operatorname{LHR}(\mathrm{o}) *(1+\mathrm{i})^{\mathrm{n}}\right)$

Tabel. 2 Perhitungan LHR Akhir Umur Rencana

\begin{tabular}{lcc}
\hline Jalan 4/2 D Lajur A - B & & \\
\hline \multicolumn{1}{c}{ Jenis Kendaraan } & LLHR A - B TAHUN 2018 & LLHR A - B TAHUN 2028 \\
\hline Kendaraan Ringan (KR) & 1236 & 2013 \\
Bus Sedang (BS) & 309 & 503 \\
Truk Sedang 2 As (Ts 2A) & 169 & 275 \\
Truk Besar 2 As (TB 2A) & 34 & 55 \\
\hline Jalan 4/2 D Lajur B - A & & \\
\hline \multicolumn{1}{c}{ Jenis Kendaraan } & LLHR B - A TAHUN 2018 & LLHR B - A TAHUN 2028 \\
\hline Kendaraan Ringan (KR) & 1189 & 1937 \\
Bus Sedang (BS) & 287 & 467 \\
Truk Sedang 2 As (Ts 2A) & 153 & 249 \\
Truk Besar 2 As (TB 2A) & 27 & 44 \\
\hline
\end{tabular}

Sumber : Data Olahan (2018)

\section{Menentukan Angka Ekivalen menurut Distribusi Beban Sumbu Kendaraan}

1. Pada jenis kendaraan ringan

Berat total maksimum $=2$ ton

$$
\begin{aligned}
\mathrm{E} & =\left[\frac{5096 \times 2}{8,16}\right]^{4}+\left[\frac{5096 \times 2}{8,16}\right]^{4} \\
& =0,00023+0,00023 \\
& =0,00046
\end{aligned}
$$

2. Pada jenis kendaraan bus sedang

Berat total maksimum $=8$ ton

$$
\begin{aligned}
E & =\left[\frac{3496 \times 8}{8,16}\right]^{4}+\left[\frac{6696 \times 8}{8,16}\right]^{4} \\
& =0,01235+0,17530 \\
& =0,18765
\end{aligned}
$$

3. Pada jenis kendaraan truk sedang 2 As

Berat total maksimum $=10$ ton

$$
\begin{aligned}
\mathrm{E} & =\left[\frac{3496 \times 10}{8,16}\right]^{4}+0,086\left[\frac{6696 \times 10}{8,16}\right]^{4} \\
& =0,03014+0,03681 \\
& =0,06695
\end{aligned}
$$

4. Pada jenis kendaraan truk besar 2 As

Berat total maksimum $=13$ ton 


$$
\begin{aligned}
\mathrm{E} & =\left[\frac{3496 \times 13}{8,16}\right]^{4}+0,086\left[\frac{6696 \times 13}{8,16}\right]^{4} \\
& =0,08609+0,10512 \\
& =0,19121
\end{aligned}
$$

Tabel.3 Perhitungan Beban Sumbu Kendaraan

\begin{tabular}{lrrrrrr}
\hline \multirow{2}{*}{ Jenis Kendaraan } & \multirow{2}{*}{ Beban } & \multicolumn{2}{c}{ Pembebanan Sumbu } & \multicolumn{2}{c}{ Ekivalen } \\
Depan & Belakang & Depan & Belakang & Total \\
\hline Kendaraan Ringan & 2 ton & 1,00 ton & 1,00 ton & 0,00023 & 0,00023 & 0,00046 \\
Bus Sedang & 8 ton & 2,72 ton & 5,28 ton & 0,01235 & 0,17530 & 0,18765 \\
Truk Sedang 2 As & 10 ton & 3,40 ton & 6,60 ton & 0,03014 & 0,03681 & 0,06695 \\
Truk Besar 2 As & 13 ton & 4,42 ton & 8,58 ton & 0,08609 & 0,10512 & 0,19121 \\
\hline
\end{tabular}

Sumber : Data Olahan, 2018

Menentukan Lintas Eqivalen Permulaan (LEP $=\Sigma($ LHR awal umur rencana $x$ E total $x$ C)

Tabel. 4 Perhitungan Lintas Ekivalen Permulaan (LEP)

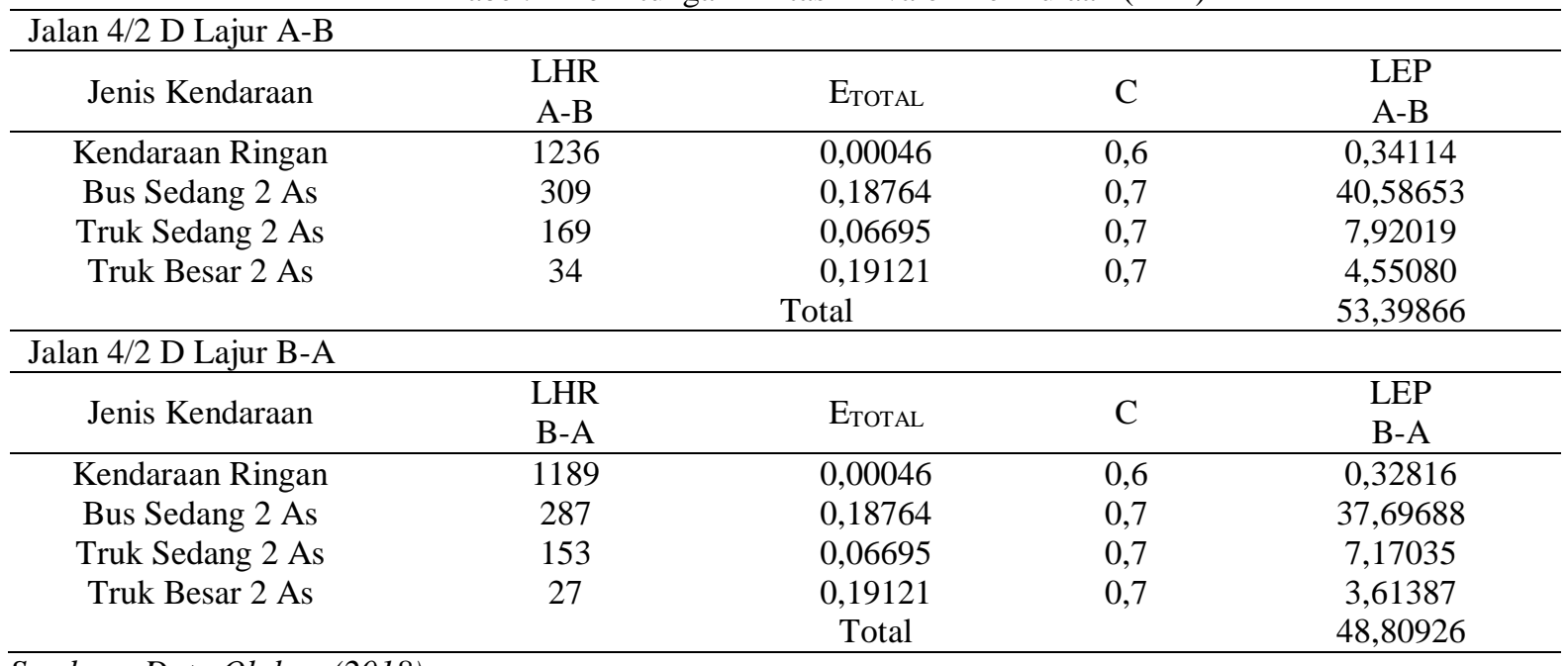

Sumber : Data Olahan (2018)

\begin{tabular}{|c|c|c|c|c|}
\hline \multicolumn{5}{|l|}{ Jalan 4/2 D Lajur A - B } \\
\hline Jenis Kendaraan & $\begin{array}{c}\mathrm{LHR}_{\mathrm{A}} \\
\mathrm{A}-\mathrm{B}\end{array}$ & $\mathrm{E}_{\mathrm{TOTAL}}$ & $\mathrm{C}$ & $\begin{array}{l}\text { LEA } \\
\text { A-B }\end{array}$ \\
\hline Kendaraan Ringan & 2013 & 0,00046 & 0,6 & 0,55559 \\
\hline Bus Sedang 2 As & 503 & 0,18764 & 0,7 & 66,06804 \\
\hline Truk Sedang 2 As & 275 & 0,06695 & 0,7 & 12,88788 \\
\hline \multirow[t]{2}{*}{ Truk Besar 2 As } & 55 & 0,19121 & 0,7 & 7,36159 \\
\hline & & \multicolumn{2}{|c|}{ Total } & 86,87310 \\
\hline \multicolumn{5}{|l|}{ Jalan 4/2 D Lajur B - A } \\
\hline Jenis Kendaraan & $\begin{array}{c}\mathrm{LHR}_{\mathrm{A}} \\
\mathrm{B}-\mathrm{A}\end{array}$ & $\mathrm{E}_{\text {TOTAL }}$ & $\mathrm{C}$ & $\begin{array}{l}\text { LEA } \\
\text { B-A }\end{array}$ \\
\hline Kendaraan Ringan & 1937 & 0,00046 & 0,6 & 0,53461 \\
\hline Bus Sedang 2 As & 467 & 0,18764 & 0,7 & 61,33952 \\
\hline Truk Sedang 2 As & 249 & 0,06695 & 0,7 & 11,66939 \\
\hline \multirow[t]{2}{*}{ Truk Besar 2 As } & 44 & 0,19121 & 0,7 & 5,886611 \\
\hline & & \multicolumn{2}{|c|}{ Total } & 79,43279 \\
\hline
\end{tabular}

\section{Menentukan Lintas EqivalenAkhir ( $\Sigma$ (LHR akhir umur rencana $x$ E total $x$ C)}

Tabel.5 Perhitungan Lintas EkivalenAkhir (LEA) untuk 10 tahun 
Menentukan Lintas Eqivalen Tengah $($ LET $=1 / 2 x$ LEA + LEP $)$

Dari data, dapat dihitung LET, yaitu :

LET10Lajur A-B $=1 / 2 \times(53,39866+86,87310)=70,13588$

LET10Lajur B-A $=1 / 2 \times(48,80926+79,43279)=64,12103$

Menghitung Lintas EqivalenRencana (LER = LET $x$ UR/10)

LER10Lajur A-B = LET $\times$ UR/10

$\begin{aligned} & =70,13588 \times 10 / 1 \\ \text { LER10Lajur B-A } & =\text { LET } \times \text { UR/10 }\end{aligned}$

$$
=64,12103 \times 10 / 10=64,12
$$

Jadi diambil LER tertinggi dari Lajur A-B yaitu 70 sebagai pedoman untuk titik di kertas nomogram.

Penentuan Harga CBR segmen menggunakan metode grafis

Tabel.6 Susunan Data CBR Dari Yang Terkecil Ke Yang Terbesar

\begin{tabular}{ccc}
\hline STA & Data CBR & Data CBR dari yang terkecil ke yang terbesar \\
\hline $0+000$ & 2,8 & 2 \\
$0+200$ & 2,7 & 2,4 \\
$0+400$ & 2,6 & 2,6 \\
$0+600$ & 2,7 & 2,6 \\
$0+800$ & 2,7 & 2,6 \\
$1+000$ & 2,6 & 2,6 \\
$1+200$ & 2,7 & 2,6 \\
$1+400$ & 2,6 & 2,6 \\
$1+600$ & 2,7 & 2,6 \\
$1+800$ & 2,7 & 2,7 \\
$2+000$ & 2,6 & 2,7 \\
$2+200$ & 2,7 & 2,7 \\
$2+400$ & 2,6 & 2,7 \\
$2+600$ & 2,8 & 2,7 \\
$2+800$ & 2,4 & 2,7 \\
$3+000$ & 2 & 2,7 \\
$3+200$ & 2,6 & 2,8 \\
$3+400$ & 2,6 & 2,8 \\
\hline
\end{tabular}

Sumber : Data Olahan (2018)

Tabel. 7 Persentase data nilai CBR yang sama atau lebih besar

\begin{tabular}{cccc}
\hline CBR, \% & $\begin{array}{c}\text { Jumlah data dengan nilai CBR } \\
\text { yang sama atau lebih besar }\end{array}$ & $\begin{array}{c}\text { Komulatif dari jumlah data } \\
\text { yang sama atau lebih besar }\end{array}$ & $\begin{array}{c}\text { Komulatif persen data yang } \\
\text { sama atau lebih besar }\end{array}$ \\
\hline 2 & 1 & 18 & $100 \%$ \\
2,4 & 1 & 17 & $17 / 18 \times 100 \%=94 \%$ \\
2,6 & 7 & 16 & $16 / 18 \times 100 \%=89 \%$ \\
2,7 & 7 & 9 & $9 / 18 \times 100 \%=50 \%$ \\
2,8 & 2 & 2 & $2 / 18 \times 100 \%=11 \%$ \\
& & & \\
\hline
\end{tabular}

Sumber : Data Olahan (2018) 


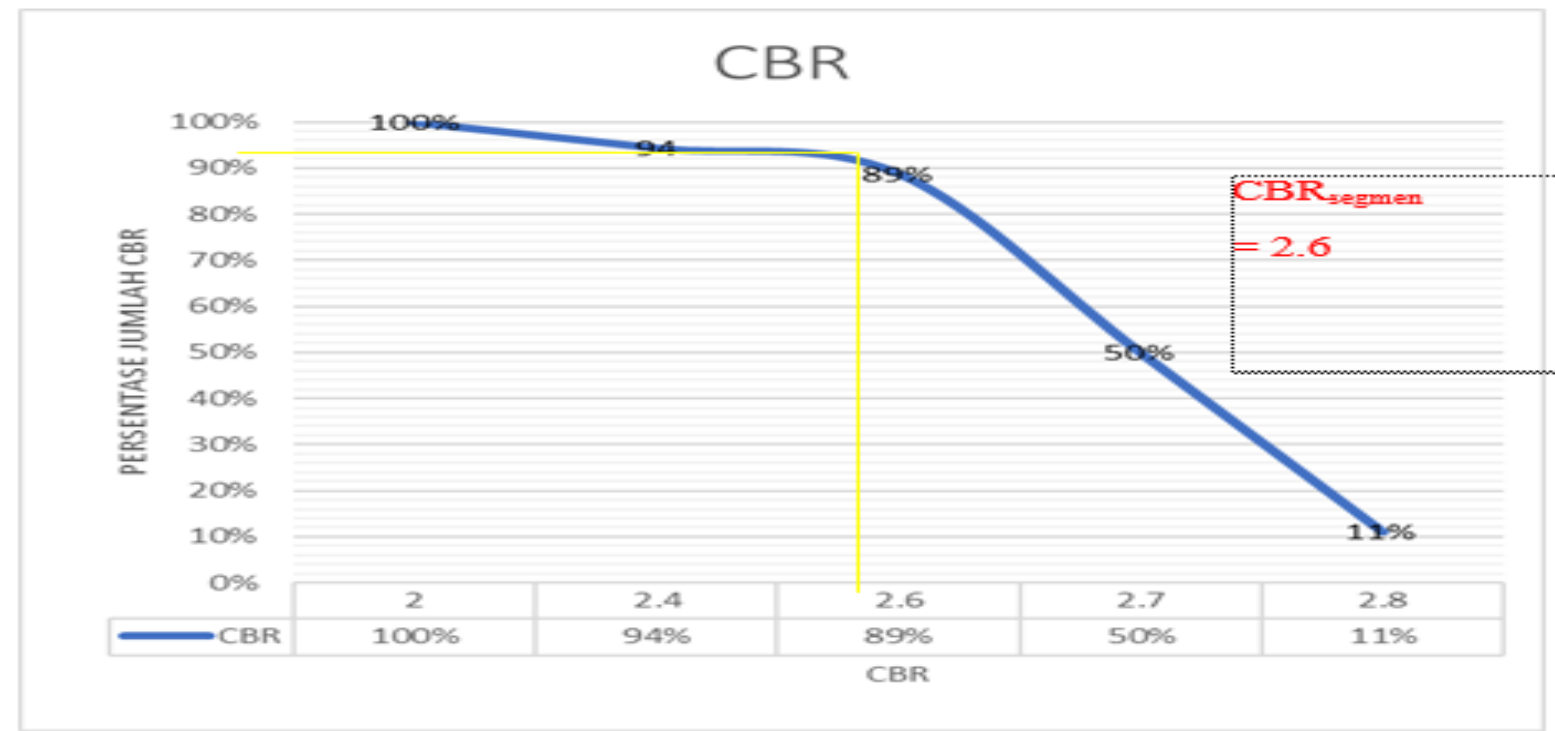

Sumber : Data Olahan (2018)

Gambar. 5 CBR segmen dengan metode Grafis

Jadi didapat CBR segmen $=2,6$

\section{Menentukan Tebal Lapisan Perkerasan}

a. Menentukan Nilai DDT (Daya Dukung Tanah)

$$
\begin{aligned}
\text { DDT } & =4,3 \times \log (\text { CBRsegmen })+1,7 \\
& =4,3 \times \log (2,6)+1,7 \\
& =3,5
\end{aligned}
$$

b. Menentukan Faktor Regional (FR)

Persentase kendaraan berat $=$ Jumlah Kendaraan Berat $x 100$ Jumlah Semua Kendaraan

$$
\text { - } \text { Lajur A-B }=\frac{512 \times}{1748} \times 100=29,29
$$

- Lajur B-A $\quad=\frac{467}{1656} \times 100=28,20$

Dari data yang diberikan di ketahui :

- Curah hujan $497 \mathrm{~mm} / \mathrm{tahun}=\mathrm{Iklim} \mathrm{I}<900 \mathrm{~mm} /$ tahun

- Jumlah kendaraan berat maksimum 29,29\%

- Landai Jalan 6-10\% = Kelandaian II

Nilai FR dapat kita lihat pada tabel Faktor Regional.

Maka Faktor Regional yang didapat adalah $=1,0$

c. CBR tanah dasar

Nilai CBR yang didapat melalui metode grafis adalah 2,6.

d. Indeks Permukaan (IP)

Untuk mendapatkan nilai Indeks Permukaan (IP) dari nilai LER dapat di lihat pada Indeks Permukaan Pada Akhir Umur Rencana (IP). Nilai LER tertinggi untuk 10 (sepuluh) tahun kedepan adalah 70,13 . Dengan klasifikasi jalan kolektor.

LER10 $=70,13=10-100$ IP yang digunakan $=1,5-2,0$

e. Indeks Permukaan (IP) pada awal umur rencana (ITP)

ITP dapat ditentukan melaluigrafik nomogram. Untuk menentukan ITP dari grafik nomogram diperlukan data sebagai berikut, IP, IPo, DDT, LER dan FR. Untuk menentukan angkaIPo, dapat dilihat pada table dibawah ini : 
Tabel. 8 Indeks Permukaan pada Awal Umur Rencana

\begin{tabular}{lcc}
\hline \multicolumn{1}{c}{ Jenis Lapis Perkerasan } & Ipo & Roughness $(\mathrm{mm} / \mathrm{km})$ \\
\hline LASTON & $\geq 4$ & $\leq 1000$ \\
LASBUTAG & $3,9-3,5$ & $>1000$ \\
& $3,9-3,5$ & $\leq 2000$ \\
HRA & $3,4-3,0$ & $>2000$ \\
& $3,9-3,5$ & $\leq 2000$ \\
BURDA & $3,4-3,0$ & $>2000$ \\
BURTU & $3,9-3,5$ & $<2000$ \\
LAPEN & $3,4-3,0$ & $<2000$ \\
& $3,4-3,0$ & $\leq 3000$ \\
LATASBUM & $2,9-2,5$ & $>3000$ \\
BURAS & $2,9-2,5$ & \\
LATASIR & $2,9-2,5$ & \\
JALAN TANAH & $2,9-2,5$ & \\
JALAN KERIKIL & $\leq 2,4$ & \\
\hline
\end{tabular}

Sumber :Petunjuk Pelaksanaan Tebal Perkerasan Jalan Raya dengan metode Analisa komponen (Kementrian pekerjaan Umum,1987).

Dari tabel dan grafik nomogram didapat hasil :

$\begin{array}{lll}\text { - } \mathrm{IP} & = & 1,5-2,0 \\ \text { - IPo } & = & 3,9-3,5 \\ \text { - } \mathrm{DDT} & = & 3,5 \\ \text { - } \mathrm{LER} & = & 70,1 \\ \text { - } \mathrm{FR} & = & 1\end{array}$

Maka diperoleh :

ITP $=7,5$ menggunakan nomogram 4 dan 5.

f. Menetapkan tebal perkerasan

Variabel - variabel untuk menetapkan lapisan tebal perkerasan dilihat pada tabel-tabel berikut ini :

Koefisien kekuatan relatif, dilihat dari tabel 2.14 koefisien kekuatan relatif
- Lapis Permukaan
: Laston, MS 454
a1 $=0,35$
- Lapis Pondasi atas
: Batu pecah kelas A a2
$=0,14$$$
=0,13
$$

- Lapis Pondasi bawah : Batu pecah kelas
Tebal lapisan minimum dilihat dari ITP $=7,5$

ITP $=\left(a_{1} x_{1} d_{1}\right)+\left(a_{2} x_{d} d_{2}\right)+\left(a_{3} x_{d_{3}}\right)$

$7,5=\left(0,35 \mathrm{xd}_{1}\right)+(0,14 \times 15)+(0,13 \times 20)$

$7,5=\left(0,35 \mathrm{xd}_{1}\right)+2,10+2,60$

$\mathrm{d}_{1}=\frac{7,5-4,70}{0,35}=8 \mathrm{~cm}$

ITP $=\left(a_{1} \times d_{1}\right)+\left(a_{2} x_{2} d_{2}\right)+\left(a_{3} x_{3}\right)$

$7,5=(0,35 \times 8)+\left(0,14 \mathrm{x} \mathrm{d}_{2}\right)+(0,13 \times 20)$

$7,5=2,8+\left(0,14 \mathrm{xd}_{2}\right)+2,60$

$\mathrm{d}_{2}=\frac{7,5-5,40}{0,14}=15 \mathrm{~cm}$

ITP $=\left(a_{1} \mathrm{xd}_{1}\right)+\left(\mathrm{a}_{2} \mathrm{x} \mathrm{d}_{2}\right)+\left(\mathrm{a}_{3} \mathrm{xd}_{3}\right)$

$7,5=(0,35 \times 8)+(0,14 \times 15)+\left(0,13 \mathrm{x} \mathrm{d}_{3}\right)$

$7,5=2,8+2,1+\left(0,13 \times \mathrm{xd}_{3}\right)$

$\mathrm{d}_{3}=\frac{7,5-4,90}{0,13}=20 \mathrm{~cm}$

- Lapis permukaan

- Lapis Pondasi atas

: Batu pecah kelas A

$\mathrm{d} 1=8 \mathrm{~cm}$

$\mathrm{d} 2=15 \mathrm{~cm}$ 


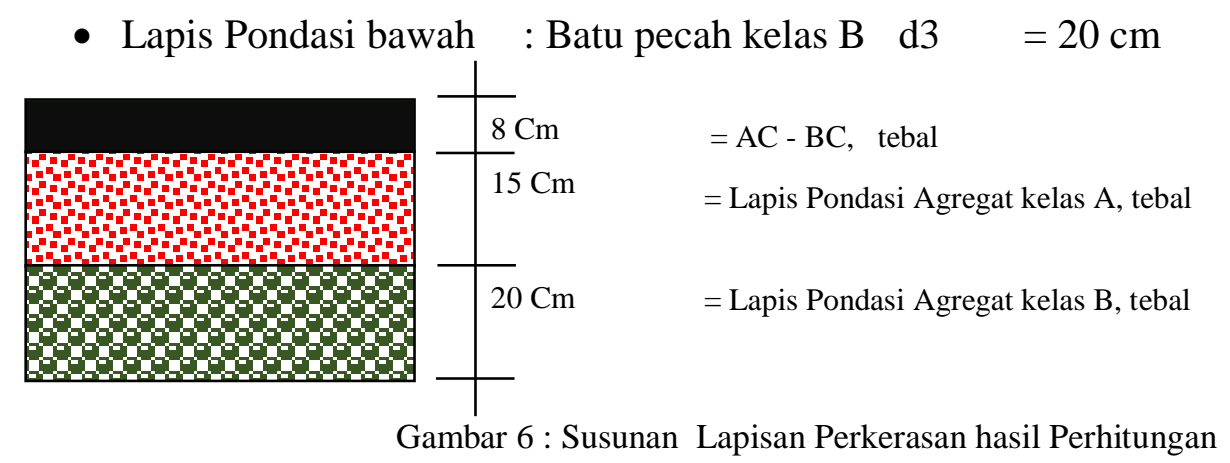

Dari hasil perhitungan angka yang dicoba dengan nilai CBR segmen yaitu 2,6 maka nilai d1 atau Lapis permukaan (Laston ) adalah $8 \mathrm{~cm}$.

\section{SIMPULAN}

1. Volume lalu lintas tahun 2018 untuk jalur $\mathrm{A}-\mathrm{B}=4849$ dan untuk jalur $\mathrm{B}-\mathrm{A}=4266$.

2. CBR tanah dasar hasil rata - rata pada penelitian ini adalah $2,6 \%$.

3. Material yang digunakan untuk lapisan perkerasan jalan adalah Surface digunakan Laston MS 454, Base Course adalah Batu pecah kelas A, dan Subbase Course adalah Batu pecah kelas B.

4. Dari hasil analisa tebal perkerasan jalan tersebut adalah dengan Lapis permukaan berdasar analisa komponen tebal $8 \mathrm{~cm}$ menggunakan lapisan base $15 \mathrm{~cm}$ dan subbase $20 \mathrm{~cm}$.

5. Struktur perkerasan jalan pada proyek peningkatan jalan simpang Talang Babat - Pangkal Bulian tidak menggunakan AC - Base dikarenakan mengikuti kondisi awal struktur perkerasan jalan yang ada.

6. Berdasarkan perhitungan tersebut didapat lapis tambah yang diperlukan adalah $4 \mathrm{~cm}$.

\section{DAFTAR PUSTAKA}

Afrialdi, Idil .2017.Kajian Analisis Lapis Perkerasan Jalan (AC-BC) Teluk Dawan - Teluk Buan Kec. Dendang Kab. Tanjung Jabung Timur. Jambi. Universitas Batanghari.

Dinas Pekerjaan Umum dan Perumahan Rakyat Kabupaten Tanjung Jabung Timur. 2017. Data California Bearing Ratio (CBR). Kabupaten Tanjung Jabung Timur. Bidang Bina Marga.

Kementerian Pekerjaan Umum Republik Indonesia, Departemen Pekerjaan UmumSKBI 2.3.26. 1987. Petunjuk Perencanaan Tebal Perkerasan Lentur Dengan Metode Analisa Komponen. Jakarta. Yayasan Badan Penerbit Pekerjaan Umum.

Kementerian Pekerjaan Umum Republik Indonesia. 2010. Spesifikasi Umum Divisi 6 (Revisi 3). Jakarta. Ditjend Bina Marga.

L. Hendarsin, Shirley. 2000. Perencanaan Teknik Jalan Raya. Bandung : Politeknik Negeri Bandung.

Sudarsono, DU. 1993. Konstruksi Jalan Raya.Jakarta : Dunia Grafika Indonesia

Sukirman, Silvia. 2003. Beton Aspal CampuranPanas. Jakarta: Granit.

Sukirman, Silvia. 2010. Perencanaan Tebal Perkerasan Lentur. Bandung: Nova.

Undang- Undang Republik Indonesia Nomor 38 Tahun 2004 Tentang Jalan.

Undang - Undang Republik Indonesia Nomor 22Tahun 2009 Tentang Lalu Lintas Dan Angkutan Jalan.

Tenri ajeng, Andi Tenri sukki. 2002. Rekayasa Jalan Raya 2. Jakarta : Guna darma 